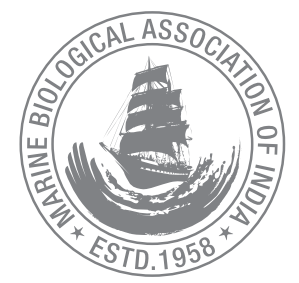

\title{
Length-weight relationships of three reef-associated fishes Lutjanus gibbus, Pinjalo lewisi and Pristipomoides filamentosus off Kochi, southwest coast of India
}

\author{
Livi Wilson*, T. M. Najmudeen, P. U. Zacharia, K. T. S. Sunil and M. Radhakrishnan \\ ICAR-Central Marine Fisheries Research Institute, Kochi-682 018, Kerala, India. \\ *Correspondence e-mail: liviwilson@gmail.com
}

Received: 02 Dec 2019 Accepted: 25 Dec 2019 Published: 30 Dec 2019

Original Article

\begin{abstract}
Length-weight relationships (LWRs) of three reef-associated fishes belonging to the family Lutjanidae viz., Lutjanus gibbus (Forsskal, 1775), Pinjalo lewisi Randall, Allen \& Anderson, 1987 and Pristipomoides filamentosus (Valenciennes, 1830), were estimated based on 548 samples collected from trawl net and hook and line fishery off Kochi, southwest coast of India. Sampling was done at Kochi (Lat. 09 $56^{\prime} 327^{\prime \prime} \mathrm{N}$, Long. 76¹5'764"E) and Munambam (Lat. $10^{\circ} 10^{\prime} 965^{\prime \prime} \mathrm{N}$, Long. $76^{\circ} 10^{\prime} 258^{\prime \prime} \mathrm{E}$ ) landing centers from May 2017 to November 2019. The estimated coefficient (b value) ranged from 2.597 ( $P$. lewisi, $\mathrm{N}=89$ ) to 2.902 ( $P$. filamentosus, $\mathrm{N}=240$ ). Coefficient of determination ( $r^{2}$ ) ranged from 0.906 (L. gibbus) to 0.952 ( $P$. filamentosus), indicating a strong functional LWRs that were highly significant $(p<0.001)$. The study reports the new maximum total length $\left(\mathrm{TL}_{\max }\right)$ for $P$. lewisi and also records first estimates of length-weight relationships for three major species of snappers from the region. The generated LWR parameters will be of great importance in evaluating the biological changes in fish stocks and for developing sustainable management measures for snappers in the southeastern Arabian Sea.
\end{abstract}

Keywords: length-weight relationships, snapper, reef-associated fishes, Southeastern Arabian Sea

\section{Introduction}

Snappers are one among the economically important groups of fishes along the southwest coast of India caught mainly by multiday trawlers and hook and lines operating in the rocky outgrowths and coral reef grounds having a wide depth range varying from 5-300 m. During 2018, the estimated landings of snappers in India were 11,668 t which constituted $3.17 \%$ to the total perch landing. Along Kerala coast, the estimated landing of snappers in 2018 was 9,75.9 t (CMFRI, 2019). Fifteen species of snappers were landed along the Kerala coast, of which, the crimson jobfish Pristipomoides filamentosus (Valenciennes, 1830) formed the dominant species. P. filamentosus along with the humpback red snapper Lutjanus gibbus (Forsskal, 1775) and slender pinjalo Pinjalo lewisi Randall, Allen and Anderson, 1987 together contributed $24.1 \%$ to the snapper landings of the region. They fetch good price owing to high demand in both the local and export markets.

The mathematical relationship between length and weight of fishes (LWR) is one of the practical reliable key for understanding their growth, maturity, reproduction, metamorphosis, survival, and the health status (Le Cren, 
1951). Also, the LWRs of fishes is an important fishery management tool to understand fish population dynamics and growth patterns on fish stocks (Froese, 2006). They also play a significant role in comparing the morphological variations between different populations of the same species in different geographical regions (Goncalves et al., 1997). The notable works in this direction on snappers along the Indian coast are by Rangarajan (1973), Oomen (1976), Premalatha (1989), Hamsa et al. (1994), Abdurahiman et al. (2004), Ramachandran et al. (2013), Pradeep (2018) and Velamala et al. (2019). The length-weight relationships of snappers are not well documented in the southeastern Arabian Sea except for a few reports (Oomen, 1976; Premalatha, 1989; Abdurahiman et al., 2004 and Ramachandran et al., 2013). However, there is little information on the LWRs of $L$. gibbus, $P$. lewisi and P. filamentosus off Kochi, southwest coast of India. The present study aims to provide information on LWRs of three species of snappers for the first time from the coast of Kerala along southwest coast of India.

\section{Material and methods}

L. gibbus $(\mathrm{N}=219)$, P. lewisi $(\mathrm{N}=89)$, and P. filamentosus $(\mathrm{N}=240)$ were sampled on a fortnightly basis from the commercial catch (trawl net and hook and line) during May 2017 to November 2019 at the two major landing centers (Cochin-Lat. 09 $56^{\prime} 327^{\prime \prime} \mathrm{N}$, Long. 76 $15^{\circ} 764^{\prime \prime} \mathrm{E}$ ) and Munambam-Lat. $10^{\circ} 10^{\prime} 965^{\prime \prime} \mathrm{N}$, Long. $\left.76^{\circ} 10^{\prime} 258^{\prime \prime} \mathrm{E}\right)$, of southwest coast of India. All the specimens (548) were sexed, length measured to the nearest $1 \mathrm{~mm}$ (total length, $\mathrm{TL}$ ) and weighed to the nearest $0.1 \mathrm{~g}$ (weight, $\mathrm{W}$ ). The LWRs were calculated using the equation: $\mathrm{W}=\mathrm{a} \mathrm{L}^{\mathrm{b}}$ where $\mathrm{W}$ is the total weight $(\mathrm{g}), \mathrm{L}$ is the total length $(\mathrm{cm})$ and; ' $a$ ' and ' $b$ ' are the regression coefficients (Froese, 2006). Prior to regression analysis, length and weight data of individual specimens were logarithmically transformed into $\log W=$ $\log a+b \log L$. To this modified LWR expression, the leastsquare fitting method was applied to generate regression coefficients and coefficient of determination (Garcia, 2010). Analysis of covariance (ANCOVA; Goldberg and Scheiner, 1993) was employed to test the statistical significance of differences between sexes. The Student's t-test (Zar, 1999) was used to predict any significant deviation in the isometric condition ( $b=3$ for LWR).

\section{Results and discussion}

The length range of $L$. gibbus, $P$. lewisi, and $P$. filamentosus in the samples collected from off Kochi, southwest coast of India were $17.5-48.5,34-79.5$ and $27.5-83.0 \mathrm{~cm}$ respectively and their size distribution is presented in Fig. 1-3. The estimated length-weight relationship parameters are presented in Table
1. In the present study, the value of LWR parameter ' $b$ ' for all the three species of snapper was found to be consistent and were within the expected range of 2.5 to 3.5 (Froese, 2006) which refers that their present growth status is quite well (Fig. 1). The study also reports the new maximum total

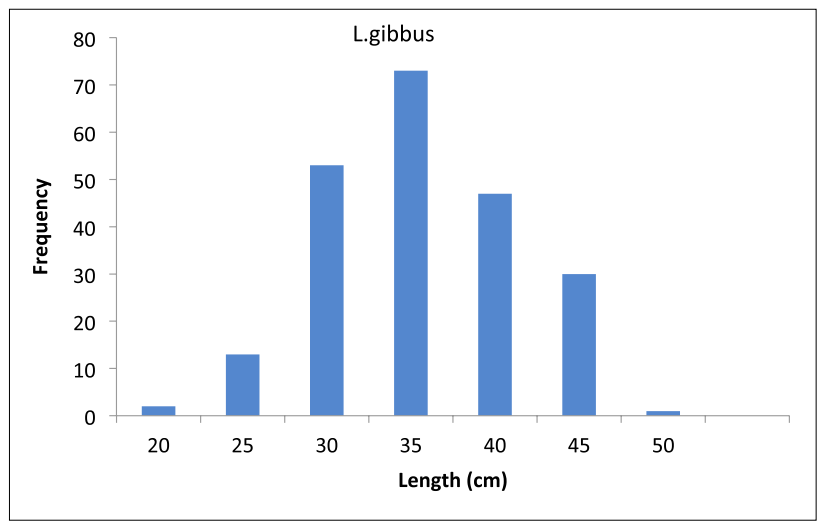

Fig. 1. Length frequency histogram for $L$. gibbus in the samples collected off Kochi, India

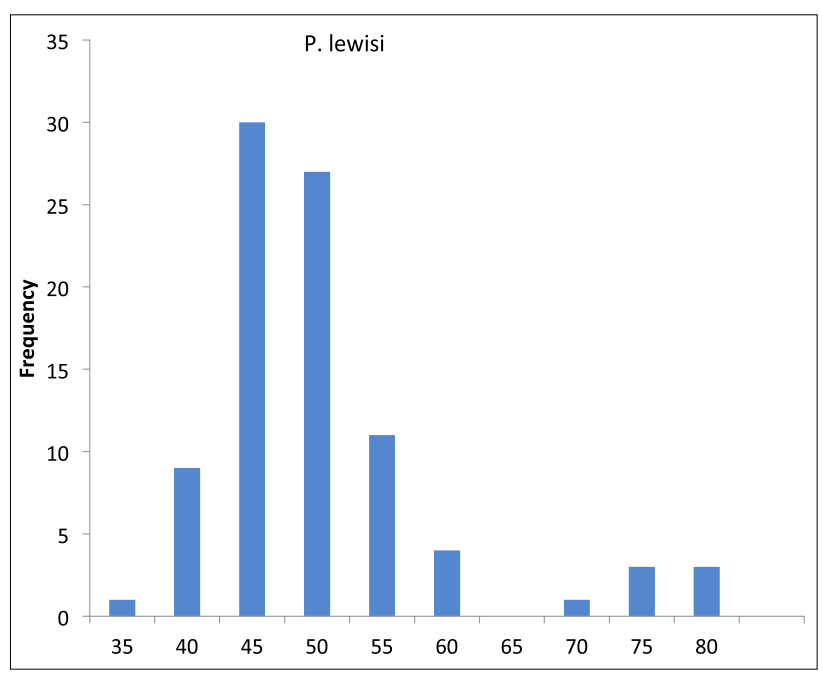

Fig. 2. Length frequency histogram for $P$. lewisi in the samples collected off Kochi, India

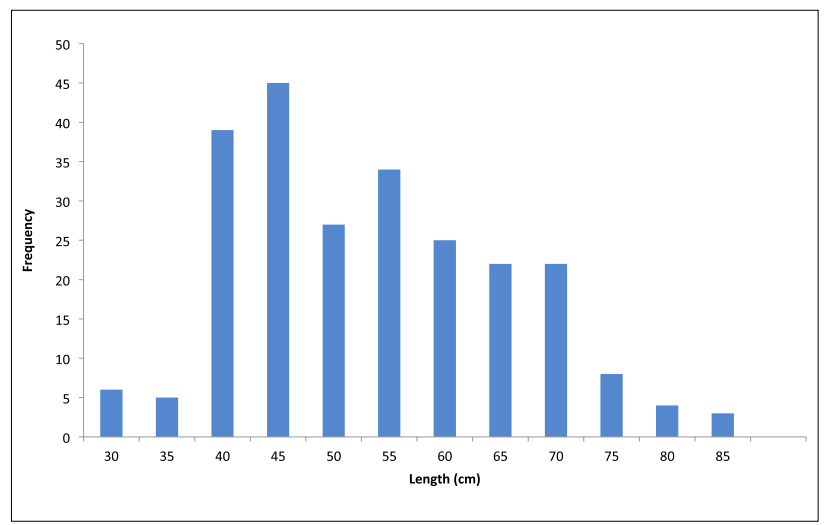

Fig. 3. Length frequency histogram for $P$. filamentosus in the samples collected off Kochi, India 
Livi Wilson et al.

Table 1. Descriptive statistics and estimated length-weight relationship parameters of three species of snappers sampled off Kochi, southwest coast of India from May 2017 November 2019

\begin{tabular}{|c|c|c|c|c|c|c|c|c|c|}
\hline Species & Sex & N & $\begin{array}{l}\text { Total length } \\
\text { range }(\mathrm{cm})\end{array}$ & a & $95 \% \mathrm{Cl}$ a & $b$ & $95 \% \mathrm{Cl} b$ & $r^{2}$ & Relationship \\
\hline \multirow[t]{3}{*}{ Lutjanus gibbus } & M & 128 & $25.3-48.5$ & 0.04496 & $0.02479-0.08154$ & 2.68679 & $2.51804-2.85555$ & 0.92972 & Allometric \\
\hline & $\mathrm{F}$ & 91 & $17.5-42.2$ & 0.03973 & $0.02223-0.07100$ & 2.71616 & $2.54621-2.88611$ & 0.95465 & Allometric \\
\hline & $P$ & 219 & $17.5-48.5$ & 0.02878 & $0.01889-0.04384$ & 2.79203 & $2.67152-2.91253$ & 0.90575 & Allometric \\
\hline \multirow[t]{3}{*}{ Pinjalo lewisi } & M & 46 & $34-79.5$ & 0.07090 & $0.03799-0.13232$ & 2.58313 & $2.42178-2.74448$ & 0.958514 & Allometric \\
\hline & $\mathrm{F}$ & 43 & $34.7-71$ & 0.03841 & $0.01426-0.10345$ & 2.73277 & $2.47345-2.99210$ & 0.915025 & Allometric \\
\hline & $P$ & 89 & $34-79.5$ & 0.06528 & $0.03791-0.11242$ & 2.59738 & $2.45645-2.73831$ & 0.939114 & Allometric \\
\hline \multirow{3}{*}{$\begin{array}{l}\text { Pristipomoides } \\
\text { filamentosus }\end{array}$} & M & 129 & $35.3-83$ & 0.02593 & $0.01537-0.04377$ & 2.78254 & $2.64369-2.92140$ & 0.968235 & Allometric \\
\hline & $\mathrm{F}$ & 111 & $27.5-55.7$ & 0.01087 & $0.00731-0.01617$ & 3.01338 & 2.90727-3.11949 & 0.987689 & Isometric \\
\hline & P & 240 & $27.5-83$ & 0.01517 & $0.01094-0.02105$ & 2.90289 & $2.81927-2.98650$ & 0.951583 & Allometric \\
\hline
\end{tabular}

M: male; F; Females; P: male and female pooled; N: number of specimen studied; a: intercept of relationship; b: slope of relationship; Cl: confidence interval; $r^{2}$ : coefficient of determination.

length $\left(\mathrm{TL}_{\max }\right)$ for $P$. lewisi (Table 1) than that reported in FishBase (Froese and Pauly, 2019). Linear regression was highly significant $(p<0.001)$ with $r^{2}$ values ranging from 0.906 ( $L$. gibbus, both sexes pooled) to 0.988 (P. filamentosus, female). The estimated allometric coefficient ' $\mathrm{b}$ ' ranged from 2.583 ( $P$. lewisi, male) to 3.013 (P. filamentosus, female). The analysis of covariance indicated that there was no significant difference in the length-weight relationships between the sexes of all the species analysed except $P$. filamentosus. All the three species exhibited negative allometric growth for pooled sexes, i.e., $\mathrm{b}<3$ (the fish grows faster in length than in weight) (Table 1). Females of $P$. filamentosus were the only ones that exhibited isometric growth $(b=3)$ which indicates that the fish increases in length and weight proportionately or at the same rate. The unchanging body form and the specific gravity of $a$ fish would yield a regression coefficient value $b=3$, which describes isometric growth (Ricker, 1975).

The length of $L$. gibbus in the samples ranged from 17.5-48.5 $\mathrm{cm}$ with a maximum size distribution in the class interval of 30 $35 \mathrm{~cm}$ (Fig. 1). The LWRs of Humpback red snapper (L. gibbus) were as follows (Fig. 4):

Male: $\log W=-3.10+2.68 \log L\left(r^{2}=0.929\right)$

Female: $\log W=-3.22+2.71 \log L\left(r^{2}=0.954\right)$

The corresponding parabolic equation can be expressed as follows:

Male: $\mathrm{W}=0.0449 \mathrm{~L}^{2.68}$

Female: $\mathrm{W}=0.0397 \mathrm{~L}^{2.71}$

The Analysis of covariance (ANCOVA) showed that there is no significant difference in LWRs between males and females $(P<$ 0.01 ) and hence a common equation was derived by pooling the sexes.

LWRs of pooled sexes: $\log W=-3.548+2.792 \log L\left(r^{2}=0.905\right)$

$W=0.0287 L^{2.792}$

In the present study, the growth exponential values obtained for males (2.687), females (2.716), and for the sexes pooled (2.792) of L. gibbus indicated a negative allometric growth pattern. This finding agrees with Ali (2016) and Ontomwa et al. (2018) for L. gibbus who reported negative allometric growth for this species along the Socotra Island, Yemen and the Shimoni artisanal fishery, Kenya respectively. However, on the contrary, Martin et al. (1991) reported an isometric growth in L. gibbus with 'b' value 3.074 from samples collected off Maldives coast. There are often clear variances between

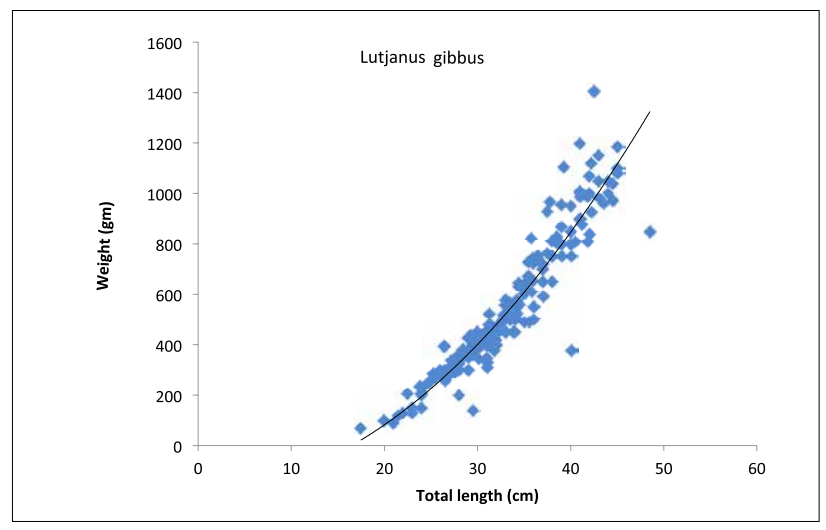

Fig. 4. Scatter diagram showing length-weight relationships of L. gibbus (sexes pooled) 
different populations of the same species, or between different years in the same population, linked with their nutritional condition (Ricker, 1975).

The length of $P$. lewisi in the samples ranged from $34.0-79.5 \mathrm{~cm}$ with the mode in the range of $40.0-45.0 \mathrm{~cm}$ (Fig. 2). The LWRs of Slender pinjalo (P. lewisi) were as follows (Fig. 5):

Male: $\log W=-2.646+2.58 \log L\left(r^{2}=0.958\right)$

Female: $\log W=-3.25+2.73 \log L\left(r^{2}=0.915\right)$

The corresponding parabolic equation can be expressed as follows:

Male: $W=0.0709 \mathrm{~L}^{2.58}$

Female: $\mathrm{W}=0.038 \mathrm{~L}^{2.73}$

The Analysis of covariance (ANCOVA) exhibited no significant difference in LWR between males and females $(P<0.01)$, hence a common equation was derived by pooling the sexes.

Pooled sexes: $\log W=-2.728+2.597 \log L\left(r^{2}=0.939\right)$

$W=0.065 L^{2.597}$

LWR for $P$. lewisi is not reported in FishBase (Froese and Pauly, 2019) or elsewhere and hence the present study represents the first report of LWR for the species.

The length of $P$. filamentosus in the samples ranged from $27.5-83.0 \mathrm{~cm}$ with a maximum size distribution in the range of $40.0-45.0 \mathrm{~cm}$ (Fig. 3). The LWRs of $P$. filamentosus were as follows (Fig. 6):

Male: $\log W=-3.652+2.78 \log L\left(r^{2}=0.968\right)$

Female: $\log W=-4.521+3.01 \log L\left(r^{2}=0.987\right)$

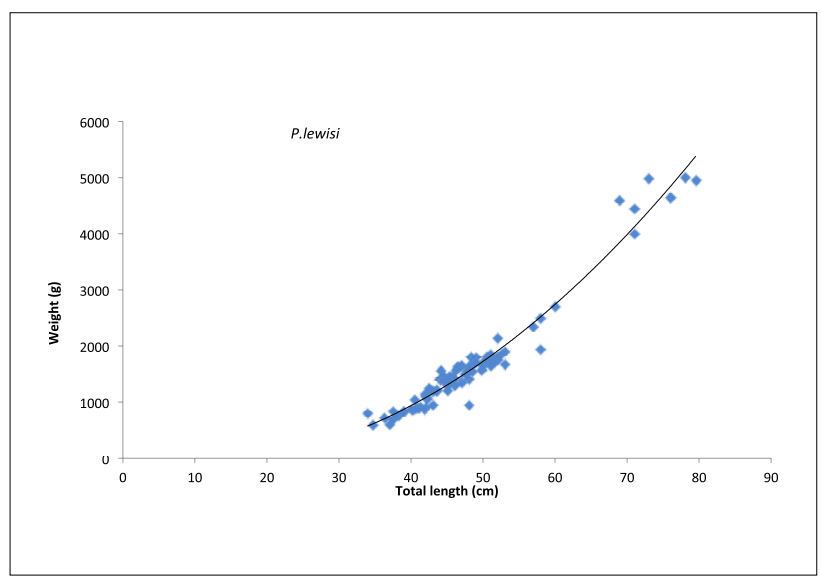

Fig. 5 Scatter diagram showing length-weight relationships of $P$. lewisi (sexes pooled)
The corresponding parabolic equation can be expressed as follows:

Male: $\mathrm{W}=0.0259 \mathrm{~L}^{2.78}$

Female: $\mathrm{W}=0.0108 \mathrm{~L}^{3.013}$

LWRs of pooled sexes: $\log W=-4.187+2.902 \log L\left(r^{2}=0.951\right)$

$W=0.0151 L^{2.902}$

The Analysis of covariance (ANCOVA) showed that there is a significant difference in LWR between males and females $(\mathrm{P}<$ 0.01 ). In the current study, the calculated allometric coefficient ' $b$ ' values obtained for males (2.783), females (3.0134), and sexes pooled (2.903) of $P$. filamentosus indicated negative allometric growth pattern for males and the combined sexes; and isometric pattern for the females. The growth pattern observed in this study for males as well as combined sexes corroborated with the opinions of Abdurahiman et al. (2004) and Mees (2005) for $P$. filamentosus documented from the south Karnataka coast of India and Mahe Plateau, Seychelles respectively. The isometric growth pattern obtained for females of $P$. filamentosus in this study was contrary to that reported by Abdurahiman et al. (2004). The growth exponential value 'b'may vary with sex, feeding, state of maturity, metabolic activity and genetic nature (Wootton, 1990).

The study provides the first documented report on the LWRs of three commercially important species of snappers viz. L. gibbus, $P$. lewisi and $P$. filamentosus along the Kerala coast. This study is relevant to fill the knowledge gap and to provide baseline information for the effective management and conservation of these species in the Arabian Sea along the southwest coast of India and it would also serve as a reference point for future research.

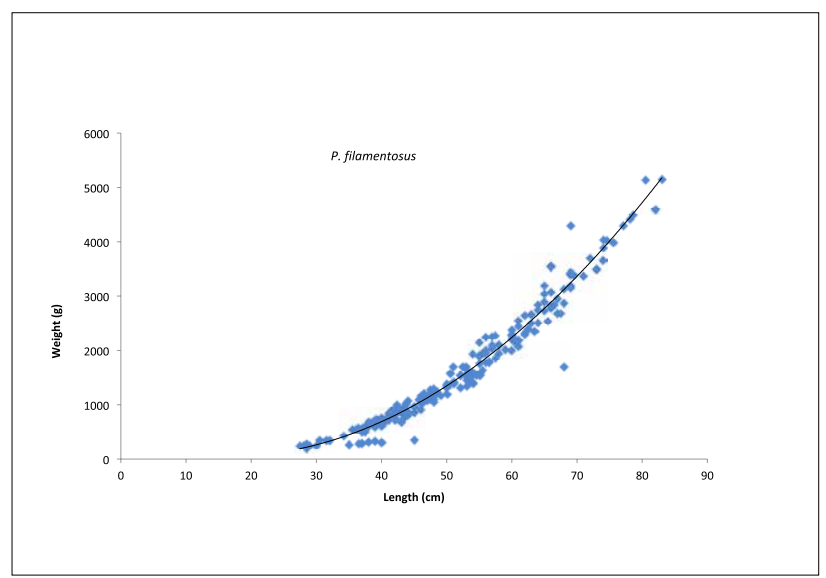

Fig.6. Scatter diagram showing length-weight relationships of P. filamentosus (sexes pooled) 


\section{Acknowledgements}

The authors thank the Director, ICAR- Central Marine Fisheries Research Institute, Cochin, India, for providing necessary support and facilities.

\section{References}

Abdurahiman, K. P., T. Harishnayak, P. U. Zacharia and K. S. Mohamed. 2004. Lengthweight relationship of commercially important marine fishes and shellfishes of the southern coast of Karnataka, India. NAGA, ICLARM Q., 27(1 \&2): 9-14.

Ali, M. K. H., A. Belluscio, D. Ventura and G. Ardizzone., 2016. Feeding ecology of some fish species occurring in artisanal fishery of Socotra Island (Yemen). Mar. Pollut. Bull., 105: 613- 628.

CMFRI. 2019. Annual report 2018-19. Central Marine Fisheries Research Institute, Kochi. 306 pp.

Froese, R. 2006. Cube law, condition factor and weight- length relationships: History, meta-analysis and recommendations. J. Appl. Ichthyol., 22 (4): 241-253.

Froese, R. and D. Pauly. 2019. Fishbase.World Wide Web electronic publication. Retrieved from http://www.fishbase.org. (accessed on $23_{\text {rd }}$ November 2019).

Garcia, L. M. B. 2010. Species composition and length-weight relationship of fishes in the Candaba wetland on Luzon Island, Philippines. J. Appl. Ichthyol., 26: 946948

Goldberg, D. E. and S. M. Scheiner. 1993. ANOVA and ANCOVA: field competition experiments. In: Scheiner, S. M., Gurevitch, J. (Eds.), Design and Analysis of Ecological Experiments. Chapman \& Hall, New York, pp. 69-93.

Goncalves, J. M. S. L. Bentes, P. G. Lino, J. Ribeiro, A. V. M. Canario and K. Erzini. 1997. Weight-length relationship for selected fish species of the small-scale demersal fisheries of the south and south-west coast of Portugal. Fish. Res., 30: 253-256.
Hamsa, K. M., S., H. Ameer Hamsa, H. M. Kasim and S. Rajapackiam. 1994. Length weight relationship of Lutjanus rivulatus off Tuticorin, Gulf of Mannar. Bull. Cent. Mar. Fish. Res. Inst., 47: 128 -129.

Le Cren, E. D. 1951.The length-weight relationship and seasonal cycle in gonad weight and condition in the perch (Perca fluviatilis). J. Anim. Ecol., 20: 201-219.

Martin Van Der Knaap, Zaha Waheed, Hussein Shareef and Mohammed Rasheed. 1991. Reef fish resources survey in the Maldives. BOBP/WP/64 p 61.

Mees, C. C. 1993.Population biology and stock assessment of Pristipomoides filamentosus on the Mahe Plateau, Seychelles. J. Fish Biol., 43: 695-708.

Ontomwa B. M. Gladys, M. Okemwa1, Edward N. Kimani and Clay Obota, 2018. Seasonal variation in the length-weight relationship and condition factor of thirty fish species from the Shimoni artisanal fishery, Kenya. WIO J. Mar Sci., 17 (1):103110.

Oommen V. P. 1976. An account of the fishery and biology of Velameen. Pristipomoides argyrogrammicus. (Valenclennes). J. Mar. Biol. Ass. India, 18:400-475.

Pradeep, H. D. 2018. Morphometrics, length frequency and length-weight relationship of the Bigeye snapper (Lutjanus lutjanus Bloch 1790) off Madras coast southeast coast of India. Indian J. Mar. Sci., 47 (08):1601-1606.

Premalatha, P. 1989. Fishery and biology of rock cods (Order-Perciformes) from the south-west coast of India. Indian J. Fish., 36 (4): 285-291.

Ramachandran, S., D. M. Ali and B. C. Varghese. 2013. Age, growth and maturity of brown stripe snapper Lutjanus vita Quoy and Gaimard, 1824) from south-west coast of India. J. Mar. Biol. Ass. India, 55(2):61-68.

Rangarajan, K. 1973. Length-weight relationship in the snapper, Lutianus kasmira (Forskal). Indian J. Fish., 20 (1): 205-208.

Ricker, W. E. 1975.Computation and interpretation of biological statistics of fish populations. Bull. Fish. Res. Board. Can., 191: 1-382.

Velamala, G. R., M. K. Naranji, Netto-Ferreira and A. L. Ramesh Babu Kondmudi, 2019 Length-Weight Relationships for 16 Snapper Fishes from Visakhapatnam Coast, India. Thalassas, 1-4 p.

Wootton, R. J., 1990. Ecology of Teleost Fishes (first ed.), Chapman and Hall, London, UK pp. 404.

Zar, J. H., 1999. Biostatistical Analysis, fourth ed. Prentice-Hall, New Jersy, USA. 